\title{
Predictive factors for short gastric vessels division during laparoscopic total fundoplication
}

\section{Fatores preditivos da necessidade de secção dos vasos gástricos curtos nas fundoplicaturas totais videolaparoscópicas}

Alexandre Chartuni Pereira Teixeira ${ }^{1}$; Fernando Augusto Mardiros Herbella ${ }^{1}$; Adorísio Bonadiman²; José Francisco de Mattos Farah, ACBC-SP2; José Carlos Del Grande, TCBC-SP 1

\section{A}

\begin{abstract}
Objective: to determine clinical variables that can predict the need for division of the short gastric vessels (SGV), based on the gastric fundus tension, assessing postoperative outcomes in patients submitted or not to section of these vessels. Methods: we analyzed data from 399 consecutive patients undergoing laparoscopic fundoplication for gastroesophageal reflux disease (GERD). The section of the SGV was performed according to the surgeon evaluation, based on the fundus tension. Patients were divided into two groups: not requiring SGV section (group A) or requiring SGV section (group B). Results: the section was not necessary in 364 (91\%) patients (Group A) and required in 35 (9\%) patients (Group B). Group B had proportionally more male patients and higher average height. The endoscopic parameters were worse for Group B, with larger hiatal hernias, greater hernias proportion with more than four centimeters, more intense esophagitis, higher proportion of Barrett's esophagus and long Barrett's esophagus. Male gender and grade IV-V esophagitis were considered independent predictors in the multivariate analysis. Transient dysphagia and GERD symptoms were more common in Group B. Conclusion: the division of the short gastric vessels is not required routinely, but male gender and grade IV-V esophagitis are independent predictors of the need for section of these vessels.
\end{abstract}

Key words: Fundoplication. Video-Assisted Surgery. Gastroesophageal Reflux. Gastric Fundus.

\section{INTRODUCTION}

aparoscopic total fundoplication is an effective procedure for the treatment of gastroesophageal reflux disease (GERD) ${ }^{1}$. However, some technical points are still controversial, especially the need for short gastric vessels (SGV) division². While most authors believe this step brings better results ${ }^{3-5}$, others showed similar outcomes whether SGV are divided or not or even complications attributed to SGV division 2,6-9.

This study aims to determine: (a) clinical variables that may predict the need of SGV division based on gastric fundus tension and (b) the outcomes in patients with or without SGV division.

\section{METHODS}

We retrospectively studied 399 consecutive patients (50\% male, mean age 49 years) recorded in a prospectively kept database that underwent laparoscopic total fundoplication for the surgical treatment of GERD. This study was approved by the local institutional review board. (CEP 0742/11).

Patients were questioned before the operation regarding the presence of symptoms. These were grouped into esophageal symptoms (heartburn and regurgitation), extra-esophageal symptoms (thoracic pain, respiratory symptoms, such as cough and asthma or ear, nose and throat symptoms) or dysphagia. Anthropometric variables were also recorded. Individuals with partial fundoplication, paraesophageal hernia, previous foregut operation or conversion to conventional laparotomy were excluded from the analysis.

All patients were submitted to an upper endoscopy to evaluate the presence of hiatal hernia $(\mathrm{HH})$, esophagitis and Barrett's esophagus. HH was classified according to size in $<4 \mathrm{~cm}$ or $\geq 4 \mathrm{~cm}$. Modified Savary-Miller endoscopic classification ${ }^{10}$ was used for grading esophagitis. Barrett esophagus was defined by the presence of intestinal metaplasia and classified as short-segment $(<3 \mathrm{~cm})$ or long-segment $(\geq 3 \mathrm{~cm})$. Esophageal manometry was available to review in 283 (71\%) patients. Ambulatory 24hour esophageal pHmonitoring was only performed in

1. Departamento de Cirurgia, Escola Paulista de Medicina, Universidade Federal de São Paulo - SP - Brazil; 2. Departamento de Cirurgia Geral e Oncológica, Hospital do Servidor Público Estadual de São Paulo - SP - Brazil. 
patients without esophagitis or with atypical symptoms pHmonitoring results were available for review in 62 (15\%).

Surgical technique has been previously described ${ }^{2}$ In summary, an extensive mobilization of the posterior wall of the gastric fundus followed the dissection of the distal esophagus and diaphragmatic crus in all patients. SGV division was done at the discretion of the surgeon based on tension of the gastric fundus after performing a specific maneuver ("drop-test" - Figure 1). A short-floppy total fundoplication was performed without the aid of a bougie. All procedures were performed by or under the supervision of a single experienced surgeon. Patients were grouped according to the necessity for SGV division (Group A - no division; Group B - SGV division).

Follow-up visits were scheduled for 15, 30, 90, 180 and 360 days after the surgery and then annually, irrespective of the presence of symptoms. Upper endoscopy was performed annually or earlier if the patient had any complaints related to the postoperative period. All selected patients had at least a 6-month postoperative follow-up period.

Chi-square, Student's t test and logistic regression were used when necessary. A value of $p$ was considered significant at the 0.05 level. Variables are expressed as mean \pm standard deviation.

\section{RESULTS}

SGV division was deemed not necessary in 364 (91\%) patients (Group A) but required in 35 (9\%) patients (Group B). Demographic data, symptoms distribution, endoscopic and manometric data are depicted in table 1. Group B had more males and a higher height. Endoscopic parameters were worse for group B, with larger hiatal hernias, higher proportion of hiatal hernias $>4 \mathrm{~cm}$, more severe esophagitis (Grade IV-V), higher proportion of Barrett esophagus, and higher rate of long-segment Barrett esophagus. Manometric parameters also disfavored group $B$ with decreased lower esophageal sphincter basal pressure. Only male gender and grade IV-V esophagitis stood as independent predictive factors for the need of SGV division at the multivariate analysis (Table 2).

Average follow-up was 13.8 months. Outcomes at last follow-up are depicted in table 3. Transient dysphagia and GERD symptoms were more common in Group B.

If patients at higher risk for gastric fundus tension (namely males with severe esophagitis) that did not underwent SGV division are compared to the remaining patients no difference in symptoms were noticed.

\section{DISCUSSION}

Our results show that: (a) male gender and severe esophagitis are independent predictors for the need to SGV

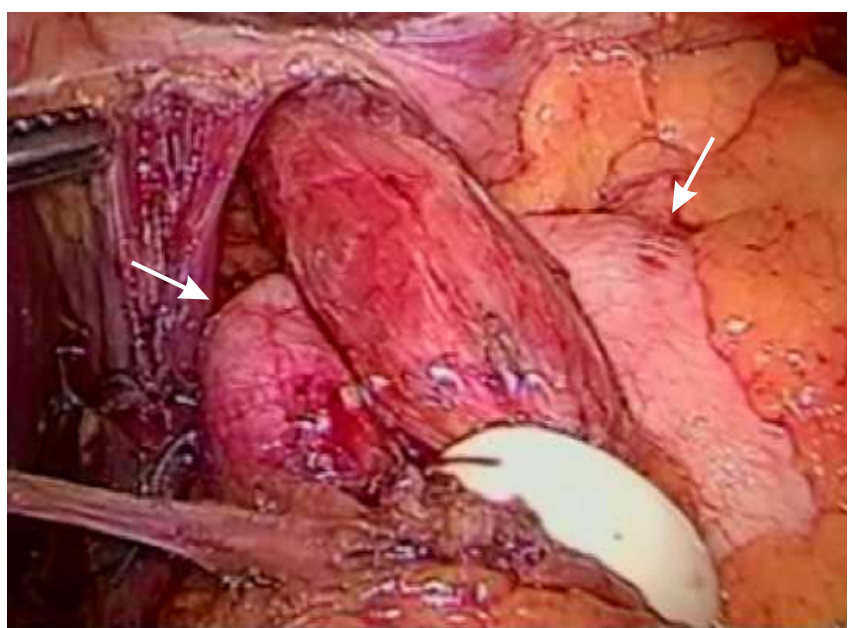

Figure 1 - Gastric fundus in place without the need of traction drop-test- (Arrows).

division and (b) SGV division may lead to more transitory dysphagia and GERD symptoms.

The effect of SGV division on the outcomes of laparoscopic fundoplication have been evaluated in five prospective randomized studies ${ }^{2,6-9}$ and their meta-analysis ${ }^{11-}$ ${ }^{14}$. These studies showed a longer operative time and intraoperative bleeding 2,6,8,9,11-14, higher incidence of transient dysphagia ${ }^{2}$ and gas-bloating syndrome ${ }^{7}$ when SGV are divided. Our results also showed more postoperative GERD symptoms. No benefit has been attributed to SGV division ${ }^{15}$. Very interestingly, however, authors that do not routinely divide SGV find this step necessary at the time of the fundoplication due to tension on the gastric fundus in up to $33 \%$ of patients ${ }^{16}$ even after extensive gastric fundus mobilization by lysis of adhesions between the stomach and diaphragm ${ }^{2,6}$.

In this study, $8.8 \%$ (35/399) of the patients needed SGVD for the completion of a short floppy fundoplication. The likely cause of this low need of SGVD is the extensive gastric fundus mobilization employed in all patients, as advocated by Farah et $a^{R}$ and Chrysos et al . We believe that when this surgical step is used, one makes a larger length of the gastric fundus available for the construction of a floppy fundoplication around the esophagus. So, even in those cases in which there is an enlarged cardia, this maneuver lessens the likelihood of the need of SGVD.

Some previous studies attempted to identify anatomic parameters to predict gastric fundus tension and consequent need to SGV division. Szor et al. ${ }^{16}$ found some sort of tension in half of the cases during fundoplications in cadavers, but no anatomic parameter predicted this tension. Huntington et al. ${ }^{17}$ deemed necessary to divided SGV in some patients based on the gastric fundus length and the esophageal circumference. Severe esophagitis as a predictor for fundus tension in our study may be linked to esophageal circumference as progressive dilatation of the esophageal 
Table 1 - Demographic data, symptoms distribution, endoscopic and manometric data.

\begin{tabular}{|c|c|c|c|}
\hline Variable & No $\operatorname{SGVD}(n=364)$ & $\operatorname{SGVD}(n=35)$ & $P$ Value \\
\hline Male & $47.3 \%$ & $80 \%$ & $<0.001 \times 2$ \\
\hline Male-female ratio & 0.89:1 & $4: 1$ & \\
\hline Mean age (sd). years & $49.77 \pm 13.05$ & $51.15 \pm 13.46$ & $0.564^{\mathrm{t}-\mathrm{s}}$ \\
\hline Mean weight (sd). $\mathrm{Kg}$ & $74.56 \pm 12.85$ & $79.76 \pm 16.86$ & $0.084^{t-5}$ \\
\hline Mean height (sd). m & $1.67 \pm 0.10$ & $1.72 \pm 0.08$ & $<0.001^{\mathrm{t}-\mathrm{s}}$ \\
\hline Mean BMI (sd). Kg/m² & $26.9 \pm 4.39$ & $26.86 \pm 5.02$ & $0.969^{t-s}$ \\
\hline \% Typical symptoms & $96.7 \%$ & $100 \%$ & $0.275^{\times 2}$ \\
\hline \% Atypical symptoms & $29.7 \%$ & $14.3 \%$ & $0.054^{\times 2}$ \\
\hline \% Dysphagia & $2.7 \%$ & $8.6 \%$ & $0.064^{\times 2}$ \\
\hline Mean duration of symptoms (sd). months & $66 \quad \pm 51.17$ & $65 \pm 41.63$ & $0.921^{\mathrm{t}-\mathrm{s}}$ \\
\hline \% Hiatal Hernia & $79.4 \%$ & $71.4 \%$ & $0.137^{\times 2}$ \\
\hline Mean hiatal hernia length (range). cm & $3 \pm 2-9$ & $3 \pm 2-10$ & $0.004^{\mathrm{t}-\mathrm{s}}$ \\
\hline$\% 2-4 \mathrm{~cm}$ & $68.7 \%$ & $48.6 \%$ & $0.016^{\times 2}$ \\
\hline$\%>4 \mathrm{~cm}$ & $10.7 \%$ & $22.9 \%$ & $0.033^{\times 2}$ \\
\hline$\%$ Esophagitis & $85 \%$ & $94 \%$ & $0.129^{\times 2}$ \\
\hline |-||-||| (Savary-Miller) & 58 & 37 & $0.019 \times 2$ \\
\hline IV-V (Savary-Miller) & 27 & 57 & $<0.001^{\times 2}$ \\
\hline$\%$ Barrett esophagus & $23.9 \%$ & $42.9 \%$ & $0.014^{\times 2}$ \\
\hline Mean size of Barrett (sd). cm & $2.17 \pm 1.68$ & $3.13 \pm 2.29$ & $0.056^{\mathrm{t}-\mathrm{s}}$ \\
\hline \% Short-segment Barrett & $18.1 \%$ & $22.9 \%$ & $0.492^{\times 2}$ \\
\hline$\%$ Long-segment Barrett & $5.8 \%$ & $20 \%$ & $0.002^{\times 2}$ \\
\hline Mean LES pressure $(\mathrm{sd}) . \mathrm{mmHg}$ & $8.74 \pm 4.98$ & $6.01 \pm 3.50$ & $0.012^{\mathrm{t}-\mathrm{s}}$ \\
\hline
\end{tabular}

SGVD: short gastric vessels division; n: number; sd: standard deviation; $y$ : years; m: meters; mo: months; cm: centimeters; LES: lower esophageal sphincter; X2: chi-square; $t$-S: Student's $t$ test.

diameter is observed as esophagitis severity increases ${ }^{18,19}$. Male gender may bring a higher chance of fundus tension probably due to more exuberant visceral fat compared to females. To the best of our knowledge, no other series studied clinical parameters to predict gastric fundus tension.

The current study studied a large number of patients; however, it has the limitations of a retrospective case series. As such, some parameters that could help understand the results of the study were not evaluated, such as the amount of visceral fat. Also, the time of followup is short for a stronger conclusion that SGV division does not affect long-term outcomes. More importantly, even though a single surgeon operated all cases, gastric fundus tension was based on subjective parameters.

We conclude that SGV division is not necessary routinely but male sex and grade IV-V esophagitis are independent predictors of the need of SGV division. However, not all patients in these conditions need SGV division as a subanalysis of these population that did not underwent this step did not show worse outcomes compared to other patients. Gastric fundus tension must still be evaluated based on subjective parameters by experienced surgeons.

Table 2 - Multivariate analysis for the need to short gastric vessels division.

\begin{tabular}{lrrr}
\hline Variable & Odds & Ratio $(95 \% \mathrm{Cl})$ & $P$ Value \\
\hline Male gender & 28.3 & $(2.25-355.22)$ & 0.010 \\
Weight & 1.03 & $(0.98-1.09)$ & 0.216 \\
Hiatal hernia length & 1.64 & $(0.75-3.59)$ & 0.213 \\
Esophagitis grade IV-V & 19.5 & $(2.08-182.26)$ & 0.009 \\
Barrett esophagus and extension & 0.11 & $(0.01-1.06)$ & 0.056 \\
LES pressure & 0.79 & $(0.62-1.01)$ & 0.063 \\
\hline
\end{tabular}

LES, lower esophageal sphincter; Cl, confidence interval. 
Table 3 - Clinical follow-up.

\begin{tabular}{|c|c|c|c|}
\hline Variable & $\begin{array}{c}\text { No SGV division } \\
n=364\end{array}$ & $\begin{array}{c}\text { SGV division } \\
n=35\end{array}$ & $P$ \\
\hline Transient dysphagia & $6 \quad(1.6 \%)$ & $4(11.4 \%)$ & 0.007 \\
\hline Persistent dysphagia & $12 \quad(3.3 \%)$ & $1 \quad(2.8 \%)$ & 1 \\
\hline Reflux symptoms & $6 \quad(1.6 \%)$ & $3 \quad(8.5 \%)$ & 0.04 \\
\hline \multicolumn{4}{|l|}{ Subgroup analysis } \\
\hline Variable & $\begin{array}{c}\text { Male sex. esophagitis IV-V, } \\
\text { no SGV division } \\
n=58\end{array}$ & $\begin{array}{l}\text { Other patients } \\
n=341\end{array}$ & $P$ \\
\hline Transient dysphagia & $4 \quad(6.9 \%)$ & $(2.3 \%)$ & 0.08 \\
\hline Persistent dysphagia & $1 \quad(1.7 \%)$ & $11 \quad(3.2 \%)$ & 1 \\
\hline Reflux symptoms & $1 \quad(1.7 \%)$ & $8 \quad(2.3 \%)$ & 1 \\
\hline
\end{tabular}

SGV: short gastric vessels.

\section{R E S U M O}

Objetivo: determinar variáveis clínicas que possam predizer a necessidade de secção dos vasos gástricos curtos (VGC), baseado na tensão do fundo gástrico, avaliando os resultados pós-operatórios em pacientes submetidos ou não à secção destes vasos. Métodos: foram analisados os dados de 399 pacientes consecutivos submetidos à fundoplicatura total laparoscópica para a doença do refluxo gastroesofágico (DRGE). A secção dos VGC foi realizada de acordo com a avaliação do cirurgião, baseado na tensão do fundo gástrico. Os pacientes foram distribuídos em dois grupos: sem necessidade de secção dos VGC (grupo A) ou com necessidade de secção dos VGC (grupo B). Resultados: A secção não foi necessária em 364 (91\%) pacientes (Grupo A) e necessária em 35 (9\%) pacientes (Grupo B). O Grupo B tinha proporcionalmente mais pacientes do sexo masculino e maior estatura média. Os parâmetros endoscópicos foram piores para o Grupo B, com maiores hérnias hiatais, maior proporção de hérnias com mais de quatro centímetros, esofagite mais intensa, maior proporção de esôfago de Barrett e esôfago de Barrett longo. O sexo masculino e as esofagites graus IV-V foram considerados fatores preditivos independentes na análise multivariada. A disfagia transitória e os sintomas de DRGE foram mais comuns no Grupo B. Conclusão: A secção dos vasos gástricos curtos não é necessária rotineiramente, porém o sexo masculino e as esofagites graus IV-V são fatores preditivos independentes da necessidade da secção destes vasos.

Descritores: Fundoplicatura. Cirurgia Vídeoassistida. Refluxo Gastroesofágico. Fundo Gástrico.

\section{REFERENCES}

1. Dallemagne B, Weerts J, Markiewicz S, Dewandre JM, Wahlen C, Monami $B$, et al. Clinical results of laparoscopic fundoplication at ten years after surgery. SurgEndosc. 2006;20(1):159-65.

2. Farah JFM, Grande JCD, Goldenberg A, Martinez JC, Lupinacci RA, Matone J. Randomized trial of total fundoplication and fundal mobilization with or without division of short gastric vessels: a short-term clinical evaluation. Acta Cir Bras. 2007;22(6):422-9.

3. Soper NJ, Dunnegan D. Anatomic fundoplication failure after laparoscopic antireflux surgery. Ann Surg. 1999;229(5):669-76; discussion 676-7.

4. Wu JS, Dunnegan DL, Luttmann DR, Soper NJ. The influence of surgical technique on clinical outcome of laparoscopic Nissen fundoplication. Surg Endosc. 1996;10(12):1164-69; discussion 1169-70.

5. Hunter JG, Swanstrom L, Waring JP. Dysphagia after laparoscopic antireûux surgery. The impact of operative technique. Ann Surg. 1996;224(1):51-7.
6. Chrysos E, Tzortzinis A, Tsiaoussis J, Athanasakis H, Vasssilakis J, Xynos E. Prospective randomized trial comparing Nissen to NissenRossetti technique for laparoscopic fundoplication. Am J Surg. 2001;182(3):215-21.

7. O’Boyle CJ, Watson DI, Jamieson GG, Myers JC, Game PA, Devitt PG. Division of short gastric vessels at laparoscopic Nissen fundoplication: a prospective double-blind randomized trial with 5-year follow-up. Ann Surg. 2002;235(2):165-70.

8. Blomqvist A, Dalenbäck J, Hagedorn C, Lönroth H, Hyltander A, Lundell L. Impact of complete gastric fundus mobilization on outcome after laparoscopic total fundoplication. J Gastrointest Surg. 2000;4(5):493-500

9. Watson DI, Pike GK, Baigrie RJ, Mathew G, Devitt PG, BrittenJones $\mathrm{R}$, et al. Prospective double-blind randomized trial of laparoscopic Nissen fundoplication with division and without division of short gastric vessels. Ann Surg. 1997;226(5):642-52.

10. Savary M, Miller G. The esophagus. Handbook and atlas of endoscopy. Solothurn, Switzerland: Grassman; 1978. p.135-42

11. Engström C, Jamieson GG, Devitt PG, Watson DI. Meta-analysis of two randomized controlled trials to identify long-term symptoms after division of the short gastric vessels during Nissen fundoplication. Br J Surg. 2011;98(8):1063-7. 
12. Markar SR, Karthikesalingam AP, Wagner OJ, Jackson D, Hewes $J C$, Vyas $S$, et al. Systematic review and meta-analysis of laparoscopic Nissen fundoplication with or without division of the short gastric vessels. Br J Surg. 2011;98(8):1056-62.

13. Khatri K, Sajid MS, Brodrick R, Baig MK, Sayegh M, Singh KK. Laparoscopic Nissen fundoplication with or without short gastric vessel division: a meta-analysis. Surg Endosc. 2012;26(4):970-8.

14. Kösek V, Wykypiel H, Weiss H, Höller E, Wetscher G, Margreiter R, et al. Division of the short gastric vessels during laparoscopic Nissen fundoplication: clinical and functional outcome during long-term follow-up in a prospectively randomized trial. SurgEndosc. 2009;23(10):2208-13

15. Bonadiman A, Teixeira AC, Goldenberg A, Farah JF. Dysphagia after laparoscopic total fundoplication: anterior or posterior gastric wall fundoplication?.Arq Gastroenterol. 2014;51(2):113-7.

16. Szor DJ, Herbella FA, Bonini AL, Moreno DG, Del Grande JC. Gastric fundus tension before and after division of the short gastric vessels in a cadaveric model of fundoplication. Dis Esophagus. 2009;22(6):539-42.
17. Huntington TR, Danielson L. Variation in fundic dimensions with respect to short gastric vessel division in laparoscopic fundoplication. SurgEndosc. 2001;15(1):76-9.

18. Csendes A, Miranda M, Espinoza M, Velasco N, Henríquez A. Perimeter and location of the muscular gastroesophageal junction or 'cardia' in control subjects and in patients with reflux esophagitis or achalasia. Scand J Gastroenterol. 1981;16(7):951-6.

19. Korn O, Csendes A, Burdiles P, Braghetto I, Stein HJ. Anatomic dilatation of the cardia and competence of the lower esophageal sphincter: a clinical and experimental study. J Gastrointest Surg. 2000;4(4):398-406.

Received on 28/09/2014

Accepted for publication 20/10/2014

Conflict of interest: none.

Source of funding: CAPES (Coordenação de Aperfeiçoamento de Pessoal de Nível Superior).

Address for correspondence:

Alexandre Chartuni Pereira Teixeira

E-mail: alexandrechartuni@gmail.com 